\title{
The Pennsylvanian Pecopteris ticleanui sp. nov. from Secu, Reşiţa Basin, Romania
}

\author{
MIHAI EMILIAN POPA \& JOSEF PŠENIČKA
}

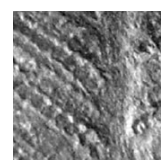

\begin{abstract}
The new species Pecopteris ticleanui sp. nov. is described and figured from Secu, Reșița Basin, South Carpathians, Romania, from the Pennsylvanian deposits of the Reșița Formation. The studied material included both mature and immature frond fragments. The species is rare in both the Reșița Basin and generally in the South Carpathians. Pecopteris ticleanui sp. nov. is an Asturian-Stephanian species, suggesting the same age for the Secu facies of the Reșița Formation. The new species belongs to a rich pecopterid assemblage which contains more than 20 pecopterid taxa. $\bullet$ Key words: Pecopteris ticleanui, Marattiales, palaeobotany, Pennsylvanian, Reșița Basin, Romania.
\end{abstract}

POPA, M.E. \& PŠENIČKA, J. 2010. The Pennsylvanian Pecopteris ticleanui sp. nov. from Secu, Reșița Basin, Romania. Bulletin of Geosciences 85(4), 663-670 (4 figures, 1 table). Czech Geological Survey, Prague. ISSN 1214-1119. Manuscript received May 26, 2010; accepted in revised form August 26, 2010; published online November 1, 2010; issued December 20, 2010.

Mihai Emilian Popa, University of Bucharest, Faculty of Geology and Geophysics, Laboratory of Palaeontology, 1, N. Balcescu Ave., 010041, Bucharest, Romania; mihai@mepopa.com • Josef P̌̌enička, West Bohemian Museum in Pilsen, Department of Paleontology, Kopeckého sady 2, 30100 Plzeň, Czech Republic; jpsenicka@zcm.cz

Marattialeans plants, most often represented by sterile pinnules called pecopterids, are known from Bashkirian macrofloras, but their global radiation occurred during the late Moscovian and Kasimovian times (DiMichele \& Phillips 2002). They became widespread in the Carboniferous world and their remains are found in almost every Carboniferous locality.

One of these localities is Secu, situated in the Reșița Basin. This basin which includes both Palaeozoic and Mesozoic continental formations, represents the largest sedimentary basin of the Getic Nappe (for summary see Bucur 1991, 1997; Popa 2009). Both Pennsylvanian and Lower Jurassic coal measures in the basin were mined for their significant coal reserves. Secu (Caraş-Severin County), located in the north-eastern part of the basin, is a former coal mine locality for Pennsylvanian anthracite, it has a large colliery tip situated along the Râul Alb (White River) valley. It represents the most important Pennsylvanian plant bearing locality of the Reșița Basin, due to both the high diversity and the degree of preservation of its fossil plants (for summary see Popa 2001, 2005, 2009), as well as for its invertebrates (Popa 2005, Jarzembowski 2008).

The Pennsylvanian continental deposits of the Reșița Basin are represented by the Reșița Formation which ranges stratigraphicaly from the uppermost Baskirian (Duckmantian) to the lower Gzhelian (Stephanian C).
The Reșița Basin was studied from a paleobotanical point of view by several authors such as Stur (1870), Hantken (1878), Mateescu (1957), Humml (1963), Maxim \& Petrescu (1970), Bițoianu (1973, 1974, 1987, 1988), Preda et al. (1984), Negrea (1987), Dragastan et al. (1997), and Popa (2001, 2009). They described a rich palaeoflora including pecopterid taxa. We have separated specimens from old collections, originally classified under different names, and new findings, using them both for defining the new species Pecopteris ticleanui sp. nov.

\section{Material}

The material was collected from the sterile dumps of the former Secu mine (Fig. 1), being represented by compressions and impressions of various sizes and degrees of preservation. The hand specimens are preserved as a dark gray claystone. Three main collections were surveyed and studied, the M.E. Popa Collection (specimens P140/C2/58 and P140/C2/230), the I. Preda Collection (specimens PR 186) and the Paleobotany Collection of the Reșița Museum, temporarily housed in the "Porțile de Fier" Museum, Drobeta Turnu-Severin (Mehedinți County) (specimens No. 23 and No. 129). The first two collections are housed within the Department of Geology and Paleontology at the University of Bucharest. 


\section{Geology and stratigraphy}

The Carboniferous system of the Reșița Basin was described in a series of relatively recent papers by Năstăseanu et al. (1973), Năstăseanu (1987), Bucur (1991), and Stănoiu et al. (1996). The Carboniferous deposits of the Reșița Basin represent relics having a much wider distribution during pre-Alpine phases, now occurring in limited areas due to tectonic and erosional factors. Many authors refered to standard 1 units such as formations and members, but the formal definition was given by Bucur (1991).

Bucur (1991) distinguished the following three members within the Reșița Formation: the Doman Member (Bolsovian-Asturian), the Lupacu Bătrân Member (Asturian-Stephanian B), and the Lupac Member (Stephanian C). The continental sequence in Secu, occurring in the north-eastern part of the Reșița Basin, complicated the separation of the three distinct members due to the marginal position of this area with respect to the main basin and to depositional factors, such as the lateral migration of the depositional centre of the Reșița Formation during the Middle and Upper Pennsylvanian time interval (Stănoiu et al. 1996). Therefore, the range of this formation is only Asturian-Stephanian B (Popa 2005) including a series of stratigraphical gaps (Năstăseanu et al. 1973, Dragastan et al. 1997), for example the Cantabrian-Barruelian, and the uppermost Stephanian C (Popa 2005). Nevertheless, to date the stratigraphical gaps have not been well documented.

The sediments of the Reșița Formation are typical for the continental environment of intramontane basins being dominated by alluvial, fluvial, lacustrine and swamp facies, in a succession which starts with alluvial sediments and ends with lacustrine sediments. The basal Doman Member is dominated by conglomerates, breccias and coarse sandstone, and it lacks fossils (Năstăseanu et al. 1973). The coals are confined to the Lupacu Batrân Member and the Lupac Member (Năstăseanu et al. 1973), occurring as two coal seams in Secu.

\section{Systematics}

Class Filicopsida

Order Marattiales Engler \& Prantl, 1902

Family Asterothecaceae Engler \& Gilg, 1919

\section{Genus Pecopteris Brongniart, 1828}

\section{Pecopteris ticleanui sp. nov.}

Figure 2

1970 Pecopteris longifolia Maxim \& Petrescu, p. 286, fig. 3.
Holotype. - The specimen No. 129 was selected; from the collection of the Reșiţa Museum housed in Drobeta Turnu-Severin.

Paratype. - The specimen No. 23 was selected; from the collection of the Reșiţa Museum housed in Drobeta Turnu-Severin.

Type locality. - Secu mine sterile dump, along the Rîul Alb valley, the Reșița Basin, Romania.

Type horizon. - The Reșița Formation, within the fine sandstone sequences associated with coal seams.

Etymology. - After Professor Nicolae Țicleanu, a prominent Romanian paleobotanist and coal geologist.

Diagnosis. - Ultimate rachis longitudinally striated, $1 \mathrm{~mm}$ wide; free pinnules inserted on ultimate rachis oppositely to sub-oppositely, at angles varying between $50^{\circ}-80^{\circ}$, with bases entire, without constrictions; pinnules 20-35 mm long, 3-4 mm wide, ratio L/W 1/5-1/6; pinnule margin straight, sometime slightly undulate; pinnule apex rounded; midvein strong, straight, reaching the apex; lateral veins divided once, close to the midvein, into two arms which are decurrent against each other; lateral veins inserted at angles of $70^{\circ}-90^{\circ}$; density of lateral veins $17-20$ veins per $10 \mathrm{~mm}$.

Description. - The fronds are usually found strongly fragmented, in both mature and immature developmental stages. The rachis is thin, $1 \mathrm{~mm}$ wide, finely striated longitudinally (Fig. 2A, D, E), the pinnules are inserted on its adaxial (upper) surface (Fig. 2A, E). The pinnules are inserted obliquely to the rachis, oppositely to sub-oppositely, at angles varying between $50^{\circ}-80^{\circ}$, with their bases entire, without constrictions (Fig. 2A, C, E). The pinnules are elongated, linear, with a constant width between 3-4 mm, and lengths between 20-35 mm (Fig. 2A, C, E, F). The margins are usually straight, but sometimes they can be slightly undulated, most probably as a result of taphonomy, without clear teeth. The apex is rounded, the pinnule width decreasing abruptly towards the apex (Fig. 2A, E, F). The midvein is straight, strong and clearly marked, almost reaching the apex. The lateral veins are inserted at angles between $70^{\circ}-90^{\circ}$ to the midvein, they are usually divided only once, very early and next to the midvein, forming two arches which reach the pinnule margins perpendicularly (Fig. 2B, F). The lateral veins are always very prominent. The density of the lateral veins reaching the margin is about $17-20$ veins per $1 \mathrm{~cm}$. The immature pinnules are often falcate, narrower, with indistinguishable venation (Fig. 2D). They appear to be more or less tubular, with transversal striations caused by secondary veins which produce undulations on the external surface. 


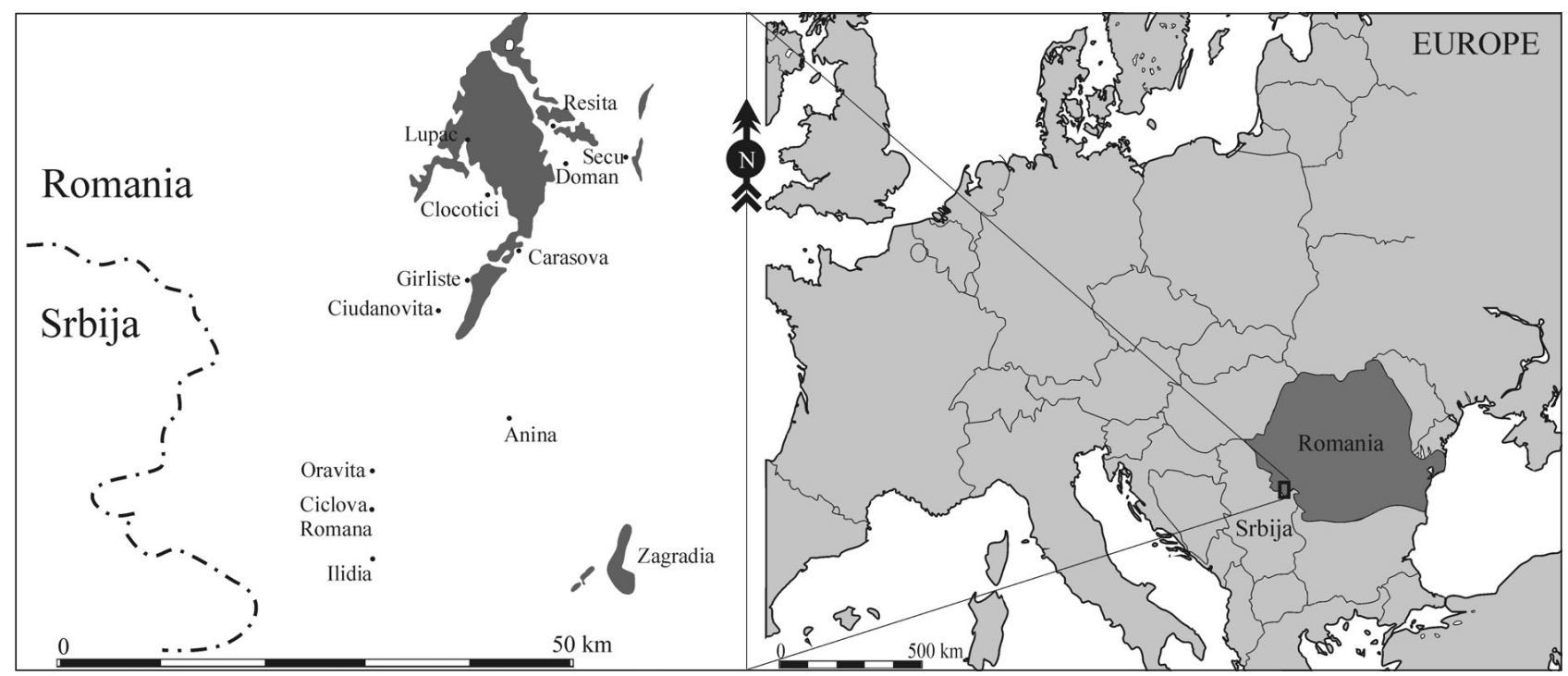

Figure 1. Locality map, showing the general position of the Secu locality in the Reșița Basin. The grey shades represent the Pennsylvanian deposits in the Reșița Basin.

Discussion. - Pecopteris ticleanui sp. nov. was described earlier from Romanian localities under different names such as Pecopteris longifolia Brongniart (Maxim \& Petrescu 1970, Bițoianu 1973) or probably (non figured) Diplazites longifolius (Brongniart) Stur (Stur 1870, Hantken 1878) or Desmopteris longifolia Stur (Popa 2005) from Romanian localities. For example Stur (1870) cited Diplazites longifolius from an occurrence near to Secu, as well as Hantken (1878), citing Diplazites longifolius (Brongniart) Stur from an occurrence near to Clocotici, and from Carașova, both of them in the Reșița Basin. Maxim and Petrescu (1970) described and illustrated Pecopteris longifolia Brongniart from Secu, based on material similar in character to Desmopteris longifolia Stur, unfortunately without a detailed description of the venation. Bițoianu $(1973,1974)$ cited Pecopteris longifolia Brongniart from Lupac, including P. longifolia var. typica Corsin, but never illustrated it. Popa (2005) considered the citations of Bițoianu $(1973,1974)$ as synonyms for Desmopteris longifolia, although due to the lack of descriptions and illustrations, these citations may also be in fact synonyms for Pecopteris ticleanui sp. nov.

Comparison of Pecopteris ticleanui sp. nov. with other pecopterids. - Pecopteris ticleanui sp. nov. shows similarities with the following species: Pecopteris platoni Grand'Eury, P. major (Doubinger) Vetter, $P$. (Diplazites) unita Brongniart, Pecopteris microphylla Corsin and P. longifolia var. stricta Corsin (Fig. 3).

The type of venation seen in Pecopteris ticleanui sp. nov., especially the character of the lateral veins, can be closely compared with the venation pattern occurring in Pecopteris (Diplazites) unita. The lateral veins of the unita-type pecopterids are undivided, or rarely once di- vided, and the veins are decurrent against each other or against the midvein. The other pecopterids have a quite different venation pattern in the dividing lateral veins. These species have divided lateral veins in which the arms of lateral veins are more or less parallel with each other. The unita-type pecopterid plant was described for the first time by Göppert (1836) under the name Diplazites emarginatus Göppert. In the same year Brongniart (1836) described the same plant under the name Pecopteris unita Brongniart. Brongniart (1836) also described another species with the unita-type venation, under the name Pecopteris longifolia Brongniart. Later Zeiller (1888) and Pšenička (2005) stated that the venation of Pecopteris (Diplazites) unita corresponded to the venation of Brongniart's Pecopteris longifolia Brongniart. Nevertheless, the pinnules of Pecopteris longifolia are elongated and narrower than those of Pecopteris (Diplazites) unita. Pecopteris longifolia was later discussed and emended by Corsin (1951). He figured more than one natural species and placed his specimens under the name Pecopteris longifolia. Some specimens (Corsin, 1951, pl. 122, fig. 2, pl. 123, figs 1, 2) appear to be pinnules from the distal end of a young pinna of Pecopteris unita as in Brongniart's (1836, pl. 116, fig. 2) specimens of Pecopteris longifolia. Corsin (1951) also mentioned that Pecopteris longifolia has Acitheca-type fertile organs. Nevertheless, he did not give further details of the fertile organs and his specimens figured in Corsin (1951, pl. 127, figs 1-3) look similar to unita-type (Ptychocarpus) reproductive organs. Based on our new, detailed observations of Brongniart's (1836) (Pecopteris unita, Pecopteris longifolia), Göppert's (1836) (Diplazites emarginatus), and Corsin's (1951) (Pecopteris longifolia) material, we assume that all of them belong to the same natural species, 
artificially named Pecopteris unita, and represented by material from different positions on a frond and at different developmental stages. If we compare Pecopteris ticleanui sp. nov. with Pecopteris unita, thus Pecopteris unita differs in its thin penultimate rachis which is $0.5 \mathrm{~mm}$ wide, pinnules which are decurrent towards the ultimate rachis, 4-6 mm long, 2-3 mm wide, ratio L/W 1/2, united in its basal part and undivided lateral veins (or very rarely divided once).

Corsins's (1951) Pecopteris longifolia var. stricta can be compared with Pecopteris ticleanui sp. nov. due to its long pinnules and their ratio L/W 1/6. But Pecopteris longifolia var. stricta has distinct lobed pinnule margins in its basal part and the midvein is clearly marked upto $1 / 5$ length of the pinnule, characters which are quite different to those seen in Pecopteris ticleanui sp. nov.

Pecopteris ticleanui sp. nov. shows great similarity with Pecopteris platoni, which was described by Grand'Eury (1890) from the Gard Basin Massive Central (France). Both species have a $1 \mathrm{~mm}$ wide ultimate rachis which is longitudinally striated, suggesting that the rachises were covered with hairs. Both species have more or less free pinnules with rounded tips. Significant similarities between the two species can be found in the type of venation. Both species have distinct midveins and lateral veins which are divided once close to the midvein. The two arms of the lateral veins are decurrent against each other. Differences between the two occur in the size of pinnules and in the position of pinnules on the ultimate rachis. Pecopteris ticleanui sp. nov. has 20-35 mm long, 3-4 mm wide pinnules, with a $\mathrm{L} / \mathrm{W}$ ratio of $1 / 6-1 / 8$ and the pinnules are inserted oppositely to sub-oppositely on the ultimate rachis. Pecopteris platoni has $10-15 \mathrm{~mm}$ long, 2-2.5 mm wide pinnules, with a $\mathrm{L} / \mathrm{W}$ ratio of $1 / 5-1 / 6$ and pinnules are situated alternately on the ultimate rachis. Pecopteris platoni also has slightly convergent pinnule margins, while Pecopteris ticleanui sp. nov. has more or less parallel pinnule margins. The relationship between the two species could be evidenced by a comparison of reproductive organs, but the reproductive organs of Pecopteris ticleanui sp. nov. are still unknown, while the reproductive organ of Pecopteris platoni were previously described.

Some similarities also occur between Pecopteris ticleanui sp. nov. and Pecopteris major (Doubinger) Vetter. Pecopteris major was originally described by Doubinger (1956) as Pecopteris cyathea var. major, but later, Vetter (1968) emended this species and established the new name as Pecopteris major, typical for Stephanian deposits. The main similarities between Pecopteris ticleanui sp. nov. and $P$. major lie in the general character of the ultimate pinnae; both have relatively long (Pecopteris ticleanui $\mathrm{sp}$. nov. $=20-35 \mathrm{~mm}, P$. major $=12-20 \mathrm{~mm}$ ) pinnules, the pinnules are inserted on the ultimate rachis oppositely to sub-oppositely, and the pinnule margins are straight. Nevertheless, Pecopteris ticleanui sp. nov. has a rounded pinnule tip, while $P$. major has a bluntly tapering pinnule tip. The significant difference between the two species is in the venation. Pecopteris ticleanui sp. nov. has lateral veins which divide once close to the midvein, and the two arms of the lateral veins decurret against each other, while Pecopteris major has lateral veins which divide once more or less parallely and are decurrent.

Another pecopterid species similar to Pecopteris ticleanui sp. nov. is Pecopteris microphylla Corsin (1951). The venation of both species is similar, having lateral veins which divide once, close to the midvein, into two arms which are decurrent against each other, and the pinnule margin is straight with a rounded tip. Nevertheless, the lateral veins of Pecopteris ticleanui sp. nov. are inserted on the midvein at angles varying between $70-90^{\circ}$, while in Pecopteris microphylla the lateral veins are inserted on the midvein at angles around $60^{\circ}$. The main difference regards the width of the pinnules, Pecopteris ticleanui sp. nov. has pinnules 3-4 mm in width, while Pecopteris microphylla has pinnules $1 \mathrm{~mm}$ in width.

Any relationship between the aforementioned species based on a comparison of the reproductive organs cannot be discussed because the reproductive organs of Pecopteris ticleanui sp. nov. are still unknown whilst the reproductive organs of Pecopteris cf. platoni, Pecopteris unita and Pecopteris longifolia were previously described by Laveine (1969).

Comparison of Pecopteris ticleanui sp. nov. with Desmopteris longifolia. - The genus Desmopteris Stur was described by Stur (1883). Earlier, Stur (1870) described $D i$ plazites longifolius from localities near to Secu (Romania). Pinnules of Pecopteris ticleanui sp. nov. can be compared with Desmopteris longifolia or D. alethopteroides. Both species are very similar in pinnule shape and venation. Desmopteris has been described and discussed by Crookall (1929), Tenchov (1977), Laveine (1989a, b), and by Cleal \& Thomas (1994).

Figure 2. Morphology of Pecopteris ticleanui sp.nov. from Secu, Reșița Basin, South Carpathians. • A - paratype, specimen No. 23; fragment of ultimate pinna, showing the pinnule shapes and insertions; scale bar: $10 \mathrm{~mm}$. B - specimen P140/C2/58; detail of pinnule showing the midvein (M), lateral veins (L) and pinnule margin; detail in Fig. F; scale bar: $1 \mathrm{~mm} . \bullet \mathrm{C}$ - specimen PR 186; fragment of ultimate pinna showing pinnule shape and insertions; scale bar: $10 \mathrm{~mm}$. $\cdot \mathrm{D}$ - specimen P140/C2/230; fragment of ultimate pinna showing an immature frond fragment with tubular-like pinnules inserted onto the rachis; scale bar: $10 \mathrm{~mm}$. $\bullet$ E - holotype, specimen No. 129; fragment of ultimate pinna showing pinnule shapes and insertions; scale bar: 10 mm. - F - specimen P140/C2/58; fragment of ultimate pinna showing the pinnules and venation, secondary veins and pinnule margin; scale bar: 5 mm. 

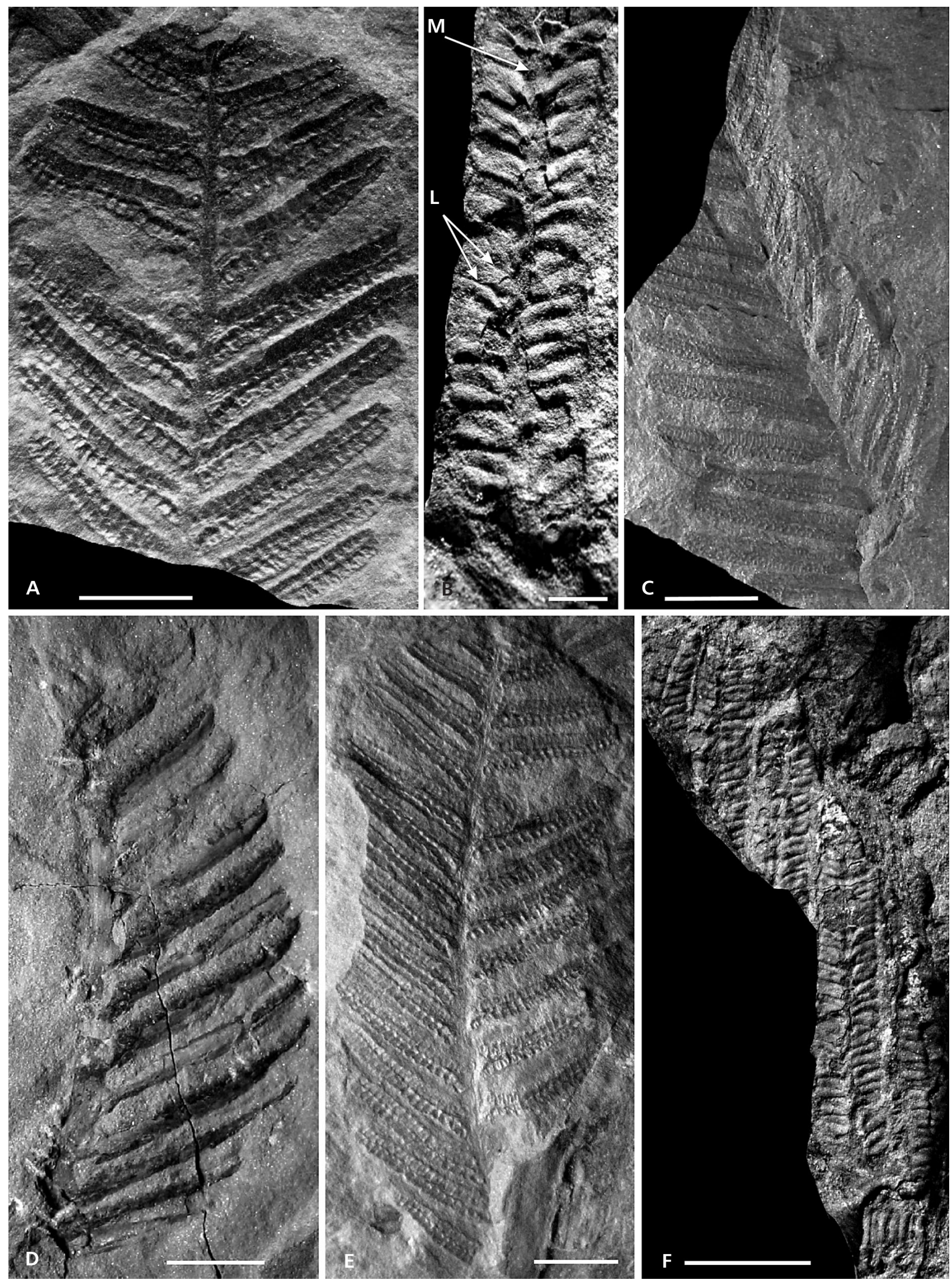

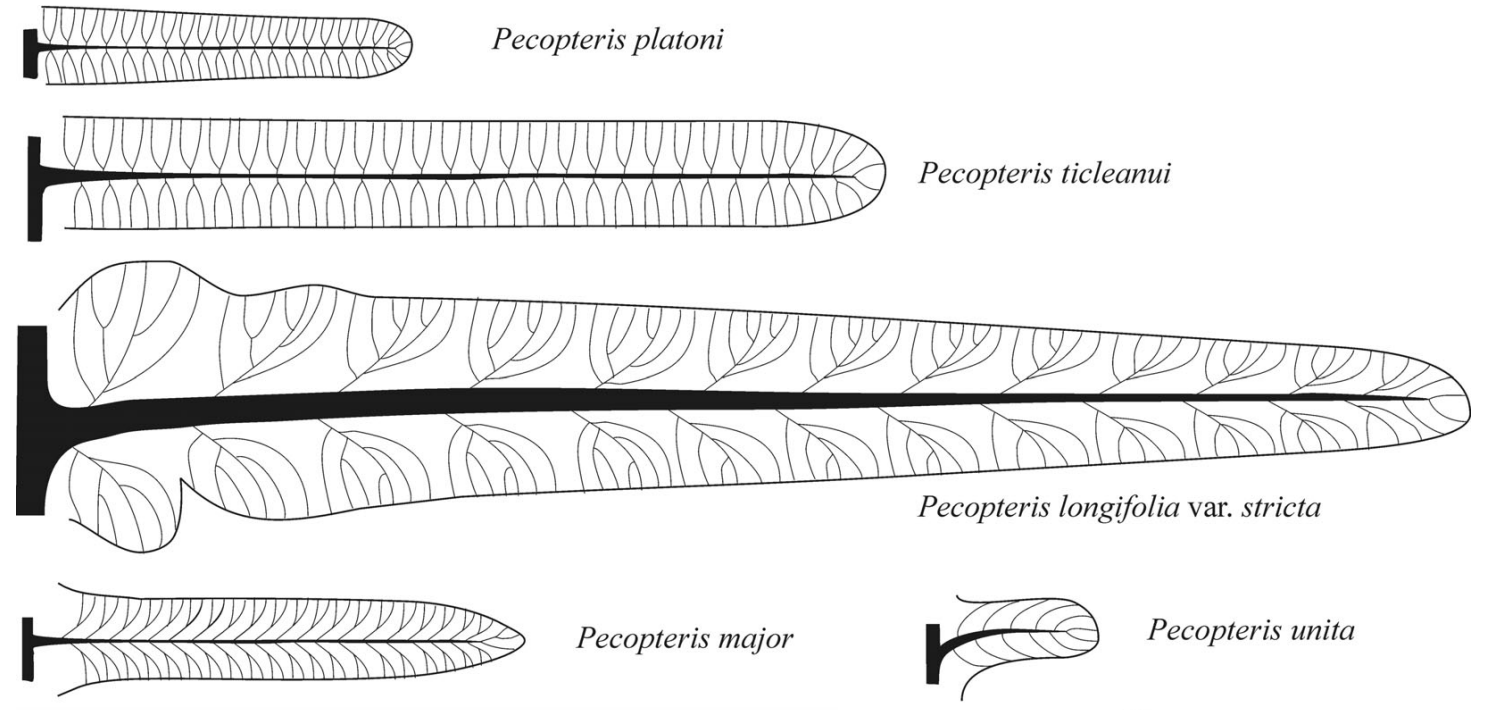

Pecopteris unita

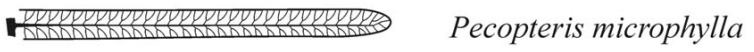

$10 \mathrm{~mm}$

Figure 3. Morphological comparison of pinnules of Pecopteris ticleanui sp.nov. with similar Marattialean species.

Some authors consider Desmopteris alethopteroides (Ettingshausen) Stur a synonym of D. longifolia (Presl) Stur, while other authors consider it to be different (Libertín et al. 2009). Libertín et al. (2009) considered Desmopteris alethopteroides as having a herbaceous habit in Central Bohemia, the Czech Republic. Opluštil et al. (2009) cited D. longifolia from the Czech localities [for example Antonín Uxa Mine, Obránců Míru Mine (both in the Pilsen Basin) and from Svinná locality and Ovčín open cast mine in the Radnice Basin], where this species is a common element of peat-forming assemblages. Both $D$. longifolia and D. alethopteroides are similar to the Romanian Pecopteris ticleanui sp. nov. material in shape and venation, but Desmopteris is always reported as having pinnules with a fine, dentate margin, a character which is not consistent with the Secu material. The dimensions of the newly collected material are generally smaller than those cited in the literature. In the case of Desmopteris longifolia, Crookall (1929) mentioned lengths between 40-90 mm, Remy \& Remy (1959) mentioned lengths up to $70 \mathrm{~mm}$, Cleal \& Thomas (1994), almost $40 \mathrm{~mm}$, while the Romanian material is $20-35 \mathrm{~mm}$ long. In Crookall's view (Crookall, 1929), as well as generally in Laveine (1989a, b), the base of the pinnules is slightly rounded and irregularly constricted (as mentioned by Brousmiche 1983), while in the Romanian material the base is entire. Also, with a density of the secondary venation of 17-20 veins per $10 \mathrm{~mm}$, the Secu material is different than that described by Cleal \& Thomas (1994), with a density lower than 15 veins per $10 \mathrm{~mm}$. The density illustrated by Remy \& Remy (1959) is about 11 veins per $10 \mathrm{~mm}$, even lower than that cited by Cleal \& Thomas (1994). Laveine (1989a, b) illustrated material with less conspicuous secondary veins than the Secu material.

\section{The association of pecopterid ferns from Secu}

Pecopterids are particularly rich in Secu, more diverse and frequent than in Lupac or anywhere else in the Reșița Basin as a result of better collecting conditions in Secu (the sterile dumps are more visibly outcropped), but also due to sedimentological factors as Secu has a more external, marginal position when compared to Lupac. We have attempted to redescribe pecopterids from Secu based on published and new material. Nevertheless, the taxa recorded by previous authors are difficult or impossible to review as many papers include only taxa lists (Stur 1870, Hantken 1878, Humml 1963, Bițoianu 1974), and rare illustrations (Bițoianu 1973, 1987, 1988; Negrea 1987; Dragastan et al. 1997) or even rarer descriptions (Mateescu 1957, Maxim $\&$ Petrescu 1970, Popa 2001). Moreover, most of the material collected and published by the previous authors has been lost, except for that of I. Maxim, H. Humml, I. Preda and M.E. Popa. It is possible to recognize 27 pecopterid taxa.

In Secu it is possible to find the following pecopterid taxa: Acitheca ambigua (C. Presl in Sternberg) Němejc, A. polymorpha (Brongniart) Schimper, Lobatopteris miltoni (Artis) Wagner, Pecopteris affinis Sternberg, P. arborescens (Schlotheim) Schlotheim ex Brongniart, $P$. bredovii Germmar, P. candolleana Brongniart, P. cyathea (Schlotheim) Stur, P. densifolia (Göppert) Weiss, P. hemitelioides Brongniart, P. (Polymorphopteris) integra (Andrae) Schimper, $P$. jongmansii Wagner, P. lepidorachis Brongniart, $P$. monyi Zeiller, $P$. oreopteroides Brongniart, $P$. palaeacea Zeiller, $P$. pectinata Corsin, $P$. permica Němejc, P . platoni Grand'Eury, P. pseudobucklandii Andrae, 
$P$. pseudooreopteridia Potonié, $P$. raconensis Němejc, $P$. rarinervosa Corsin, $P$. (Danaeites) saraefolia Bertrand, P. unita Brongniart, P. villosa Brongniart and P. (Polymorphopteris) subelegans (Potonié) Wagner.

\section{Notes on the Carboniferous stratigraphy of the Secu area}

Previous authors attempted phytostratigraphic studies of the Carboniferous deposits in the Reșița Basin. The most important are those of Bițoianu (1973, 1974, 1988), and Dragastan in Dragastan et al. (1997). The stratigraphical range of the pecopterid species from the Secu area are shown in Fig. 4. Based on the flora in the Secu area, Dragastan et al. (1997) identified Duckmantian deposits based on the occurence of Sphenophyllum majus Bronn or Paripteris gigantea (Sternberg) Gothan, Bolsovian deposits were identified based on the occurence of Alethopteris serlii (Brongniart) Goeppert and Asturian deposits based on the occurence of Neuropteris ovata Hoffman, and in the Lupac area, he recognized also Stephanian B and C sediments. However, Popa (2005) collected in the Secu area only Stephanian plant fossils such as Alethopteris zeillerii Ragot, Nemejcopteris feminaeformis (Schlotheim) Barthel or Sphenophyllum oblongifolium (Germar) Unger. Pecopterids described from Secu more or less support this suggestion. The Duckmantian and the Bolsovian ages are supported only by the occurrence of Lobatopteris miltoni. The Asturian age may be represented by several species such as Pecopteris (Danaeites) saraefolia, P. (Polymorphopteris) integra, Acitheca ambigua, P. villosa, P. raconensis and $P$. palaeacea. The Stephanian B and C may be represented by Pecopteris pseudobucklandii, P. pseudooreopteridia, $P$. jongmansii, $P$. permica and $P$. subelegans. The remaining pecopterids from the $\mathrm{Secu}$ locality have a relatively wide stratigraphical range, from the Asturian to the Permian. Nevertheless, these species are associated together with pecopterids which are characteristic for Stephanian B and $\mathrm{C}$. Based on this fact, the other pecopterids probably represent the Stephanian B and C rather than the Cantabrian or the Barruelian. The Duckmantian and the Bolsovian contain 1 pecopterid taxa, nevertheless the presence of this stratigraphical position is documented by the occurrence of some biostratigraphically important species such as Sphenophyllum majus, Paripteris gigantea or Alethopteris serlii. The Asturian contains 6 pecopterid taxa accompanied by Neuropteris ovata and the Stephanian B and C contain 20 pecopterid taxa associated with Alethopteris zeillerii, Nemejcopteris feminaeformis or Sphenophyllum oblongifolium, while the absence of large lycopsids in Secu confirm this classification.

The rapid development of pecopterid taxa across the Asturian-Cantabrian boundary was mentioned by Phillips

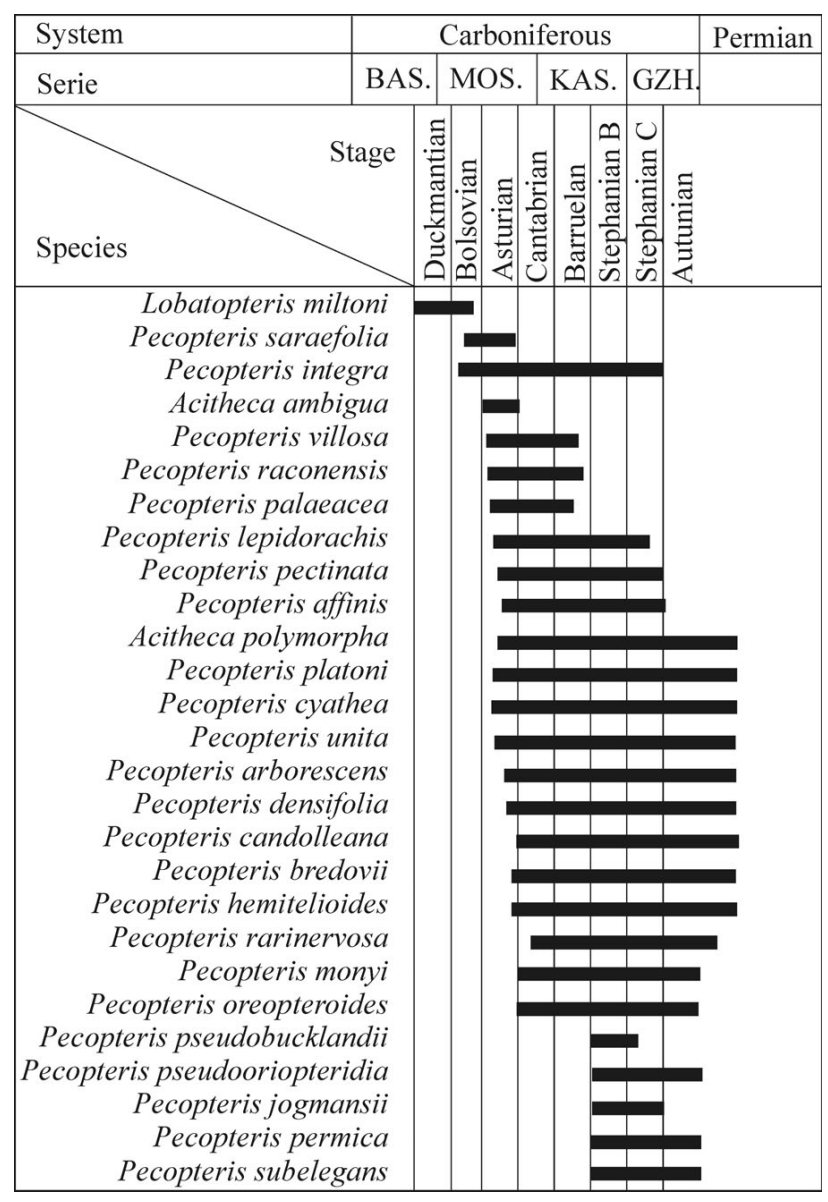

Figure 4. Stratigraphic ranges of the pecopterid species occurring in the Secu area. BAS. - Bashkirian; MOS. - Moscovian; KAS. - Kasimovian; GZH. - Gzhelian.

et al. (1985). This boundary is characterized by a rapid change when the arborescent lycopods almost died-out while species variability of tree-ferns rapidly increased. This effect is also visible in the Secu locality, as the Duckmantian, the Bolsovian and the Asturian intervals are characterized by 7 taxa, while the Stephanian is characterised by 20 taxa. This major change in plant diversification must have been a reaction to a significant, probably global, climate change.

\section{Acknowledgements}

Many thanks to Dr. Florina Diaconu ("Porțile de Fier" Museum, Drobeta Turnu-Severin) for granting access to the Reșița Museum collections, temporarily housed in Drobeta Turnu-Severin. This paper is a result of the PNII-PC research grant No. 31-063/14.09.2007 awarded to Mihai E. Popa (P.I.). The study was also supported by the Grant Agency of the Czech Republic (205/07/1059). This paper is also a part of the IGCP 575 project Pennsylvanian terrestrial habitats and biotas of southeastern Euramerica. 


\section{References}

Bițoianu, C. 1973. La flore du Carbonifere superieur de la Roumanie. Septieme Congres International de Stratigraphie et de geologie du Carbonifere, Krefeld, 115-127.

Bițoianu, C. 1974. Le Silezien des Carpathes Meridionales (Roumanie). Bulletin du Société Belge de Geologie, Paleontologie, Hydrologie 83(2), 131-133.

Brongniart, A.T. 1828-1838. Historie des végétaux fossiles, ou recherches botaniques et geologiques sur les végétaux renfermés dans les diverses couches du globe. Vol. 1, 10 (1836), 337-368. G. Dufour et D'Ocagne, Paris.

Brousmiche, C. 1983. Les fougères sphénoptéridiennes du bassin houiller sarro-lorrain. 480 pp. Société géologique Du Nord 10, Lille.

BuCUR, I.I. 1991. Proposition pour une nomenclature formelle des depots paleozoiques et mesozoiques de la zone de ReșițaMoldova Nouă (Carpathes Meridionales, Roumanie). Studia Universitatis Babeș-Bolyai, Geologie 36(2), 3-14.

BuCUR, I.I. 1997. Formațiunile mesozoice din zona Reșița-Moldova Nouă. 214 pp. Ed. Presa Universitară Clujeană, Cluj-Napoca.

Cleal, C.J. \& Thomas, B.A. 1994. Plant fossils of the British coal measures. Field guide to fossils 6.222 pp. The Palaeontological Association, London.

Corsin, P. 1951. Flore fossile de la Sarre et de la Lorraine. 4-eme fascicule. Pecopteridees. Etudes des mineraux de la France 4, Loos-Nord, 176-370.

Crookall, R. 1929. Coal measure plants. 80 pp. Edward Arnold \& Co., London.

DiMichele, W.A. \& Phillips, T.L. 2002. The ecology of Paleozoic ferns. Review of Palaeobotany and Palynology 119(2002), 143-159. DOI 10.1016/S0034-6667(01)00134-8

GÖPPERT, H.R. 1836. Die fossilen Farrnkräuter (System filicum fossilum). Verhandlungen der kaiserlichen leopoldischcarolinischen Akademie der Naturforscher (Novorum actorum Academiae Caesareae Leopoldino-Carolinae naturae coriosorum, voluminis septimi decimi supplementum) 17, 1-486.

Grand'Eury, C.F. 1890. Géologie et paléontologie du basin houiller du Gard. 324 pp. Imprimerie, Lithographie et Papeterie Fréderic Lantz, St.-Étienne.

HantKen, M.P. 1878. Die Kohlenflotze und der Kohlenbergbau in den Landern der ungarischen Krone. 331 pp. Legrady Testeverek, Budapest.

JARZEMBOwSKI, E.A. 2008. The oldest insect from Romania: a new Carboniferous blattodean. Studia Geologica Polonica 129, 43-50.

LAVEINE, J.P. 1989a. Guide paleobotanique dans le terrain houiller Sarro-Lorrain. Texte. 154 pp. Doc. des Houilleries du Bassin de Lorraine 1, 2, Lille.

LAVEINE, J.P. 1989b. Guide paleobotanique dans le terrain houiller Sarro-Lorrain. Atlas. 64 pp. Doc. des Houilleries du Bassin de Lorraine 2, Lille.

Laveine, J.P. 1969. Quelques Pécoptéridiées houilléres à la lumiére de la palynologie. Pollen et Spores 11, 619-668.

Libertín, M., Opluštil, S., PšEničKa, J., Bek, J., SÝkorová, I. \& DAšKovÁ, J. 2009. Middle Pennsylvanian pioneer plant assemblage buried in situ by volcanic ash-fall, central Bohemia, Czech Republic. Review of Palaeobotany and Palynology 155, 204-233. DOI 10.1016/j.revpalbo.2007.12.012

Maxim, I.A. \& Petrescu, I. 1970. Câteva plante fosile necunoscute din Stephanianul de la Secul (Banat). Studii si Cercetari de
Geologie, Geofizica, Geografie, seria Geologie 15(1), 283-294.

NĂSTĂSEAnU, S. 1987. Upper Palaeozoic molasse deposits in the Romanian South Carpathians, 371-378. In FLÜGEL, E., SASSI, F. \& Grecula, P. (eds) Pre-Variscan and Variscan events in the Alpine-Mediterranean mountain belts. Alfa Bratislava, Bratislava.

Năstăseanu, S., Stănoiu, I. \& Bitoianu, C. 1973. Corelarea formatiunilor molasei hercinice (Westfalian-Permian) din partea vestica a Carpatilor Meridionali. Anuarul Institutului Geologic 40, 71-109.

Opluštil, S., PŠEnIČKA, J., LiberTín, M. \& ŠIMƯNEK, Z. 2009. Vegetation patterns of Westphalian and Lower Stephanian mire assemblages preserved in tuff beds of the continental basins of Czech Republic. Review of Palaeobotany and Palynology 143, 107-154. DOI 10.1016/j.revpalbo.2006.06.004

Phillips, T.L., Peppers, R.A. \& DiMichele, W.A. 1985. Stratigraphic and interregional changes in Pennsylvanian coalswamp vegetation: Environmental inferences. International Journal of Coal Geology 5, 43-109. DOI 10.1016/0166-5162(85)90010-2

PopA, M.E. 2001. Aspects of Romanian Palaeozoic Palaeobotany and Palynology. Part I. An Acitheca type fern from Secu (Banat), 365-369. In Olaru, L. (ed.) $3^{\text {rd }}$ Romanian National Symposium of Palaeontology. Acta Palaeontologica Romaniae. Vasiliana '98, Iași.

PopA, M.E. 2005. Aspects of Romanian Palaeozoic palaeobotany and palynology. Part II. Overview of the Upper Carboniferous formations in the South Carpathians. Zeitschrift der Deutschen Gesellschaft fur Geowissenschaften 156(3), 415-430. DOI 10.1127/1860-1804/2005/0156-0415

PopA, M.E. 2009. Late Palaeozoic and Early Mesozoic continental formations of the Reșița Basin. 197 pp. Editura Universității din București, Bucharest.

PŠEnIČKA, J. 2005. Taxonomy of Pennsylvanian-Permian ferns from coal Basins in the Czech Republic and Canada. 185 pp. Ph.D. thesis, Faculty of Science, Charles University, Prague.

Remy, W. \& Remy, R. 1959. Pflanzenfossilien. 286 pp. Akademie Verlag, Berlin.

Stănoiu, I., Țicleanu, N., DiaconițĂ, D. \& Popa, M.E. 1996. Stratigrafia, faciesurile și paleoambianțele formațiunilor Carbonifer superior-Permian inferioare $\mathrm{cu}$ cărbuni din Bazinul Reșița, Simpozionul de resurse minerale, pp. 58-65. Buletin informativ, Fundația oamenilor de știință Prahova, Ploiești.

SteRnBERG, K.M. 1825. Versuch einer geognostischen botanischen Darstellung der Flora der Vorwelt. Vol. I, 4 (1825), Tent. I-XLII, 1-48. Ernst Breck's Wittwe, Regensburg.

STUR, D. 1870. Beitrage zur kenntnis der Dyas und Steinkohlenformation im Banate. Jahrbuch der kaiserlich-königlichen geologischen Reichsanstalt 20, 185-200.

Tenchov, Y.G. 1977. Fossil flora from the Stephanian-Permian outcrops in Northwestern Bulgaria. 4. Alethopteridaceae, Callipteris, Odontopteris, Gymnospermophyta Seminae. Palaeontology, Stratigraphy and Lithology 7, 3-14.

VETTER, P. 1968. Géologie et paléontologie des bassins houillers de Decazeville, de Figeac et du Detroit de Rodez. Etude paleontologique 2. Houilleres du Bassin d'Aquitaine. 192 pp. Imprimerie moderne, Aurillac.

ZeILler, R. 1888. Études des Gites Minéraux de la France. Bassin houillere de Valenciennes. Decription de la Flore fossile. 731 pp. Masion Quantin, Paris. 